\title{
Growth stanzas in an Epinephelidae-Lutjanidae complex: considerations to length-weight relationships
}

\author{
Ximena Renán ${ }^{1}$, Jorge Trejo-Martínez ${ }^{1,2}$, Doralice Caballero-Arango ${ }^{1,3} \&$ Thierry Brulé $^{1}$ \\ 1. Centro de Investigación y de Estudios Avanzados del Instituto Politécnico Nacional, Departamento de Recursos del \\ Mar, Unidad Mérida. Ant. Carr. a Progreso Km. 6. A.P. 73, Cordemex, Mérida, Yucatán, C.P. 97310. México; \\ ximenarenan@me.com, tbrule@mda.cinvestav.mx \\ 2. Galen University, 62.5 Western Highway, San Ignacio, Cayo District Belize, C.A. Belize; snapsprov@yahoo.co.uk \\ 3. Centro de Bachillerato Tecnológico, Industrial y de Servicio, Antigua carretera a Progreso Km 6 Col. Chuburna de \\ Hidalgo C.P. 97200, Yucatán, México; chacmola@hotmail.com
}

Received 30-VI-2014. Corrected 18-IX-2014. Accepted 20-X-2014.

\begin{abstract}
Growth stanzas or abrupt changes in growth rates are present throughout the life span of fish. Identifying growth stanzas will help to adequately described growth taking into account that fishes are indeterminate growers. In this study, we used length-weight (L-W) relationships to analyze the growth stanzas in the Grouper-Snapper complex of Southern Gulf of Mexico. For this, the type of sexuality, sex and different sexual maturity phase were considered in the analyses of three species of gonochoric Snappers (Lutjanidae) and six species of protogynous hermaphrodite Groupers (Epinephelidae). Welch ANOVA tests were carried out to determine the existence of differences in length and weight between juveniles and adults per sex. According to the observed differences, L-W relationship parameters ( $a$ and $b$ ), standard error ( $\mathrm{SE} b$ ) and coefficients of determination $\left(R^{2}\right)$ were calculated for all species separately by sex and sexual maturity phase. Snappers' juvenile-females $b$-value ranged from 2.44-2.77, juvenile-males from 2.16-2.94, adult-females from 2.63-2.80 and adult-males from 2.63-2.98. Groupers' $b$-value ranged for juvenile-females 2.66-3.20, adult-females from 2.73-3.31 and for adult-males 2.93-3.29. For each relationship $b$-value was $t$-tested ( $t$-Student) to explore differences from the allometric coefficient $(b=3)$, which indicated changes in body form. Hypothesis test, for regression slopes (b) between Snappers' juvenile-females vs. adult-females and juvenile-males vs. adult-males and Groupers' juvenile-females vs. adult-females and adult-females vs. adult-males, indicated different growth stanzas related to gonadal development for Snappers, and to gonadal development and sex change in Groupers. The identification of growth stanzas is crucial to avoid an overestimation or misleading growth rate which is used in fisheries management to establish some target reference points, such as maximum sustainable yield or yield-per-recruit. Rev. Biol. Trop. 63 (1): 175-187. Epub 2015 March 01.
\end{abstract}

Key words: growth stanzas, length-weight relationships, Grouper-Snapper complex, Gulf of Mexico.

Length-weight (L-W) relationships are used to assess biomass of fish populations (Keller, \& Kerstetter, 2013), as indicators of fish condition (Dubey et al., 2012), to compare life histories of certain species among regions (Pauly, 1993) or to allow the conversion of growth-in-length equations to growthin-weight for use in stock assessment models (Moutopoulos, \& Stergiou, 2002). Even though L-W relationships are commonly and widely used, there is no single regression that will adequately describe growth of a fish, because growth rate change throughout their life span. These growth rate variations may be reflected as abrupt changes in growth rate known as growth stanzas (Ricker, 1979; Froese, 2006; Katsanevakis et al., 2007). Growth stanzas could be observed in juvenile stage (pre-maturity) and/or after they reach sexual maturity (post-maturity). Pre-maturity growth models should consider that all surplus energy is devoted to somatic growth (the growth rate should 
be higher) whereas to describe post-maturity, it must be considered that some or all of the extra energy is channeled to gonadal development (Lester, Shuter, \& Abrams, 2004).

The status of most reef fish stocks is unknown in the Southeastern United States and Mexico. Reef fishes must be conservatively managed because their communities comprise slow-growing and late maturing fish such as Groupers and Snappers (Coleman, Koenig, Eklund, \& Grimes, 1999). Groupers and Snappers are top predators and play a vital ecological role in the trophodynamics of tropical environments. They face different threats to their populations such as nursery habitat destruction, juvenile extraction, and spawning aggregations exploitation. In Southern Gulf of Mexico, for the reef fishery of the Yucatan Peninsula continental shelf (Campeche Bank), nine species of the Grouper-Snapper complex (SAFMC, 2013) are the most economically important and represent almost $94 \%$ of the total number of specimens captured (Brulé, NóhQuiñones, Sánchez-Crespo, Colás-Marrufo, \& Pérez-Díaz, 2009), generating more than USD\$19 million in annual revenue (SAGARPA, 2012). Of these, three species from the Lutjanidae family (Snappers), are gonochoric: Lutjanus campechanus (Poey 1860), Lutjanus synagris (Linnaeus 1758) and Ocyurus chrysurus (Bloch 1791) whereas the other six species from the Epinephelidae family (Groupers), are protogynous hermaphrodites: Epinephelus morio (Valenciennes 1828), Epinephelus guttatus (Linnaeus 1758), Mycteroperca bonaci (Poey 1860), Mycteroperca microlepis (Goode and Bean 1880), Mycteroperca tigris (Valenciennes 1833) and Mycteroperca venenosa (Linnaeus 1758). Worldwide, E. morio, M. bonaci and $M$. venenosa populations are considered as nearly threatened (IUCN, 2013), E. guttatus, $M$. microlepis, $M$. tigris as vulnerable with declining populations (Morris, Callum, \& Hawkins, 2000) and L. campechanus as overfished in recovery (NOAA, 2011). For Southern Gulf of Mexico, E. morio populations are considered overexploited (Burgos, \& Defeo, 2004) and its fishery in danger of collapse (Burgos,
\& Pérez-Pérez, 2006). The other species have neither stock assessments nor L-W relationship records for their populations.

Few growth studies take into consideration the presence of growth stanzas to calculate L-W relationships, which may lead to a growth rate overestimation if juveniles are not separated from adults or to a misleading growth rate if relationships are calculated with joined sexes (Froese, 2006). This study aimed to analyze the presence of growth stanzas, by the use of L-W relationships, in nine species of the Grouper-Snapper complex from the Campeche Bank. We considered the type of sexuality (gonochoric and hermaphrodites), sex (females and males) and different sexual maturity phases (juveniles and sexually mature adults), and expected to provide a realistic growth scheme for each species, which may be useful for fisheries management.

\section{METHODS AND MATERIALS}

Collection site and field sampling: Specimens were collected on the Yucatan Peninsula continental shelf from 1999 to 2009, through monthly catches on a yearly basis, through a tropical sequential fishery by the artisanal (using hook and line) and technified fishing fleets (using automated long lines). Groupers were measured for total (TL $\mathrm{cm})$ and standard length $(\mathrm{SL} \mathrm{cm}$ ) except for E. guttatus (only $\mathrm{TL}$ ) and weighed for total (TW g) and gutted weight (GW g). Due to their fork tail, Snappers were measured for total (TL $\mathrm{cm})$, standard (SL cm) and fork length (FL cm) except for L. campechanus (only TL and SL), and weighed for total (TW g) and gutted weight (GW g). For all species fresh gonad weight $(\mathrm{gW} \mathrm{g})$ was recorded and gonadosomatic index $(\mathrm{IG}=100 x[\mathrm{gW} / \mathrm{GW}])$ was calculated.

Gonadal analysis: Type of sexuality, sex and gonadal developmental phase were determined for each specimen by microscopic examination of gonadal structure. Hermaphroditism was defined following the criteria established by Sadovy and Shapiro (1987) 
and Sadovy de Mitcheson and Liu (2008), and sex and gonad developmental stage following Brown-Peterson, Wyanski, Saborido-Rey, Macewicz \& Lowerre-Barbieri (2011).

Groupers analyzed in this study, are protogynic hermaphrodites (specimens undergo a sexual transition from a functional female to a functional male) (Shapiro, 1987) therefore, no juvenile-males were registered while Snappers are gonochoric species with female and males-juveniles. Considering group sample variances were unequal, Welch (Welch, 1951) ANOVA (means are weighted by the reciprocal of the group mean variances) independent tests were performed to know if there were differences in mean length (TL, FL, SL) and weight (TW, GW), regardless the magnitude, between sex and gonad developmental phase.

Following the procedure established by Ricker (1973) with the proposed modifications by Froese (2006), L-W relationships were calculated by sex and gonad developmental phase, for each species, using the equation $\mathrm{W}=\mathrm{aL}^{\mathrm{b}}$ where $W$ is total weight of the fish in grams, $L$ is total length of the fish to the nearest centimeter, $a$ the intercept and $b$ the slope following a double-logarithmic least square linear regression. It was taken into account that L-W $b$-value according to Carlander (1969) (as cited in Keller \& Kerstetter, 2013) should fall between the expected range for $b=2.5-3.5$ in fishes. The $b$-value for each relationship was afterwards $t$-tested ( $t$-Student) to explore significant statistically differences from the allometric coefficient $b=3$ (Cinco, 1982) using the equation $t=(b-3)$ sb (Sokal, \& Rohlf, 1995) where $t$ is $t$-student value, $b$ is the slope and $s b$ is the slope standard error. According to Froese (2006) $b$-value indicates changes in body form or condition: If $b=3$ individuals in the sample have the same form as large specimens, if $b>3$ specimens increased in height or width more than in length and if $b<3$ specimens become more elongated. Finally, hypothesis tests of differences between regression line slopes ( $b$-value) were performed according to Zar (1999) among gonochoric Snappers' femalejuveniles vs. female-adults and male-juveniles vs. male-adults and for protogynous hermaphrodites Groupers' juvenile-females vs. adultfemales and adult-females vs. adult-males. Statistically significant differences in $b$-value between regression slopes in each species were considered as different growth stanzas. All statistical analyses were performed using MATLAB R2012b (The MathWorks, Inc.).

\section{RESULTS}

A total of 12114 specimens of nine different species were sampled: Lutjanus campechanus $(\mathrm{N}=914)$, Lutjanus synagris $(\mathrm{N}=1022)$, Ocyurus chrysurus $(\mathrm{N}=1431)$, Epinephelus guttatus $(\mathrm{N}=1522)$, Epinephelus morio $(\mathrm{N}=2328)$, Mycteroperca bonaci $(\mathrm{N}=739)$, Mycteroperca microlepis $(\mathrm{N}=1083)$, Mycteroperca tigris $(\mathrm{N}=519)$ and Mycteroperca venenosa $(\mathrm{N}=2556)$. Gonochoric Snappers' juvenile-females ranged in total length (TL) from $13.5-49.9 \mathrm{~cm}$, juvenile-males from 14.0 $58.5 \mathrm{~cm}$, adult-females ranged form 18.5 $61.6 \mathrm{~cm}$ and adult-males form $17.7-81.6 \mathrm{~cm}$. Protogynous hermaphrodite Groupers' juvenile-females ranged form 1.9 to $61.0 \mathrm{~cm}$, adultfemales from $25.6-123.5 \mathrm{~cm}$ and adult-males from $29.0-124.5 \mathrm{~cm}$ (TL). Mean gonadosomatic index percent (IG\%) varied for Snappers: L. campechanus females (max-min monthly mean values \pm SE: $1.02 \pm 8.80-0.20 \pm 0.09 \%)$ and males $(0.24 \pm 0.40-0.09 \pm 0.03 \%)$ for L. synagris females $(3.00 \pm 0.18-0.50 \pm 0.03 \%)$ and males $(0.90 \pm 0.13-0.20 \pm 0.02 \%)$ and for $O$. chrysurus females $(2.30 \pm 0.13-0.50 \pm 0.03 \%)$ and males $(3.30 \pm 0.23-0.50 \pm 0.03 \%)$. For Groupers mean IG\% varied for E. guttatus females (max$\min$ values \pm SE: $10.57 \pm 0.71 \%-0.12 \pm 0.01 \%$ ) and males $(0.95 \pm 0.04-0.10 \pm 0.01 \%), E$. morio females $(2.14 \pm 0.21-0.07 \pm 0.02 \%)$ and males $(0.29 \pm 0.08-0.14 \pm 0.01 \%), M$. bonaci females $(2.2 \pm 0.27-0.6 \pm 0.01 \%)$ and males $(0.22 \pm 0.03-0.11 \pm 0.03 \%)$, M. microlepis females $(3.40 \pm 0.23-0.40 \pm 0.03 \%)$ and males $(0.36 \pm 0.11-0.06 \pm 0.01 \%), \quad M$. tigris females $(3.47 \pm 0.31-0.15 \pm 0.02 \%)$ and males $(1.36 \pm 0.14-0.10 \pm 0.01 \%)$ and $M$. venenosa females $(8.70 \pm 0.55-0.15 \pm 0.03)$ and males 
(5.83 $\pm 0.40-0.05 \pm 0.03 \%$ ). For all species, IG\% was higher in females than in males (except for O. chrysurus) even though females of all species tend to be smaller in size and weight.

Welch ANOVA tests showed significant statistical differences $(p<0.05)$ for all Snappers and Groupers species in TL, FL, SL, TW and GW (Table 1) between sex (females and males) and gonad developmental phase (juveniles and adults). Therefore, length-weight relationships were calculated separately for juveniles and for mature individuals per sex in Snappers and for juvenile-females, adult-females and adult-males in Groupers (Table 2). Linear regressions were significant for all species (females/males, juveniles/adults) $(p<0.05)$ and coefficients of determination ranged from 0.96 0.99 indicating a strong relationship between variables. Length-weight $b$-values for Snappers and Groupers fell between the expected 2.5-3.5 range for $b$. Snappers' $b$-values varied from 2.3 to 2.7 for juvenile-females, from 2.1 to 2.9 for juvenile-males, from 2.6 to 2.8 for adult-females and from 2.6 to 2.9 for adultmales. For Groupers, $b$-values ranged from 2.6 to 3.2 for juvenile-females, from 2.7 to 3.3 for adult-females and from 2.9 to 3.2 for adult-males (Table 2).

The $t$-test ( $t$-Student) to explore differences from the allometric coefficient $b=3$ acknowledge differences for Snappers: in juvenile-females for the three species $(b<3)$, in adult-females only for $L$. campechanus $(b<3)$, in juvenile-males for L. synagris and $O$. chrysurus $(b<3)$ and in adult-males for the three species $(b<3)$. Lutjanus campechanus juvenile-females and adult-females displayed the same $b$-value $(b<3)$ showing that specimens conserve an elongated body as they grow and mature sexually, whereas juvenile-males $(b=3)$ change their uniform body shape to an elongated one as they reach sexual maturity $(b<3)$. On the contrary, L. synagris and $O$. chrysurus displayed changes from an elongated body shape as juvenile-females $(b<3)$, to a more uniform body shape $(b=3)$ as adult-females. For both species juvenile-males and adult-males conserve the same elongated body shape $(b<3)$ as they grow and mature (Table 3). Differences from $b=3$ for Groupers were registered: in juvenile-females of $E$. morio $(b>3), M$. bonaci $(b>3)$, M. microlepis $(b>3)$ and M. tigris $(b<3)$, in adult-females for all species $(b<3$ or $b>3)$ except for M. tigris $(b=3)$ and in adult-males only for E. morio $(b>3)$ and $M$. venenosa $(b<3)$. Epinephelus morio displayed the same body shape becoming gradually thicker with size $(b>3)$. For E. guttatus juvenile-females' uniformity in body shape $(b=3)$ change to an elongated form as they reach adulthood (adultfemales $b<3$ ) and then change back to a more uniform body shape as adult-males $(b=3)$. For M. bonaci and M. microlepis juvenile-females $(b>3)$ and adult-females $(b>3)$ continuously increase in height or width more than in length, whereas through sex change, this tendency ceases and adult-males display a more uniform body shape $(b=3)$. Mycteroperca tigris exhibits changes from an elongated form in juvenilefemales $(b<3)$ to a uniform body shape as adult-females and adult-males $(b=3)$. Mycteroperca venenosa show a uniform body shape $(b=3)$ in juvenile-females, changing to an elongated form in adult-females $(b<3)$ that conserve as adult-males $(b<3)$ (Table 3 ).

Hypothesis tests on differences between regression lines slopes were performed in order to observe possible growth stanzas. Growth stanzas were accounted for Snappers' L. campechanus and L. synagris from juvenile-females to adult-females and for the three species (including O. chrysurus) from juvenile-males to adult-males. For Groupers growth stanzas could be identified in E. morio, $M$. bonaci and M. microlepis from juvenilefemales to adult-females and for E. guttatus, $E$. morio, M. microlepis and M. tigris from adultfemales to adult-males (Table 4).

\section{DISCUSSION}

Growth stanzas are characterized by some kind of crisis or discontinuity in development (Ricker, 1979) described by changes in growth rate. Since fishes are indeterminate growers, growth models should be carried out in 


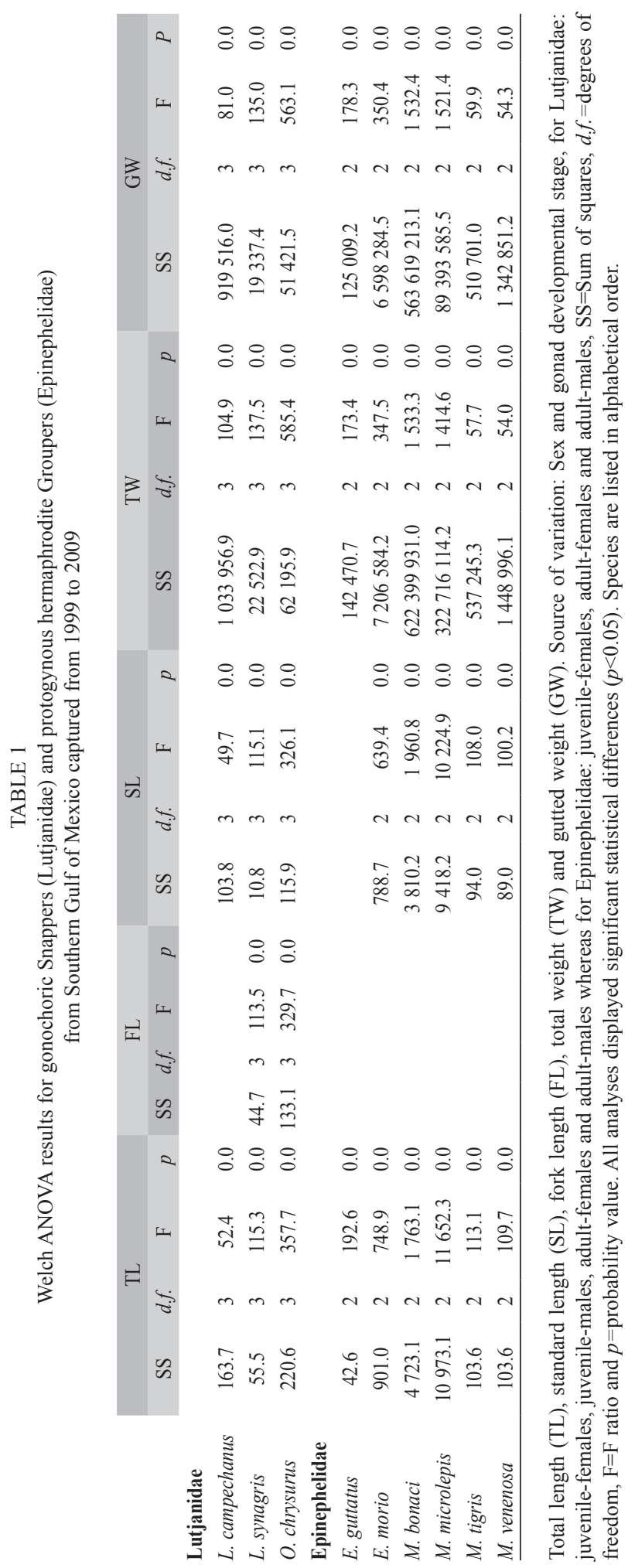

(c) (i) $\bigodot_{\mathrm{BY}}$ Rev. Biol. Trop. (Int. J. Trop. Biol. ISSN-0034-7744) Vol. 63 (1): 175-187, March 2015 


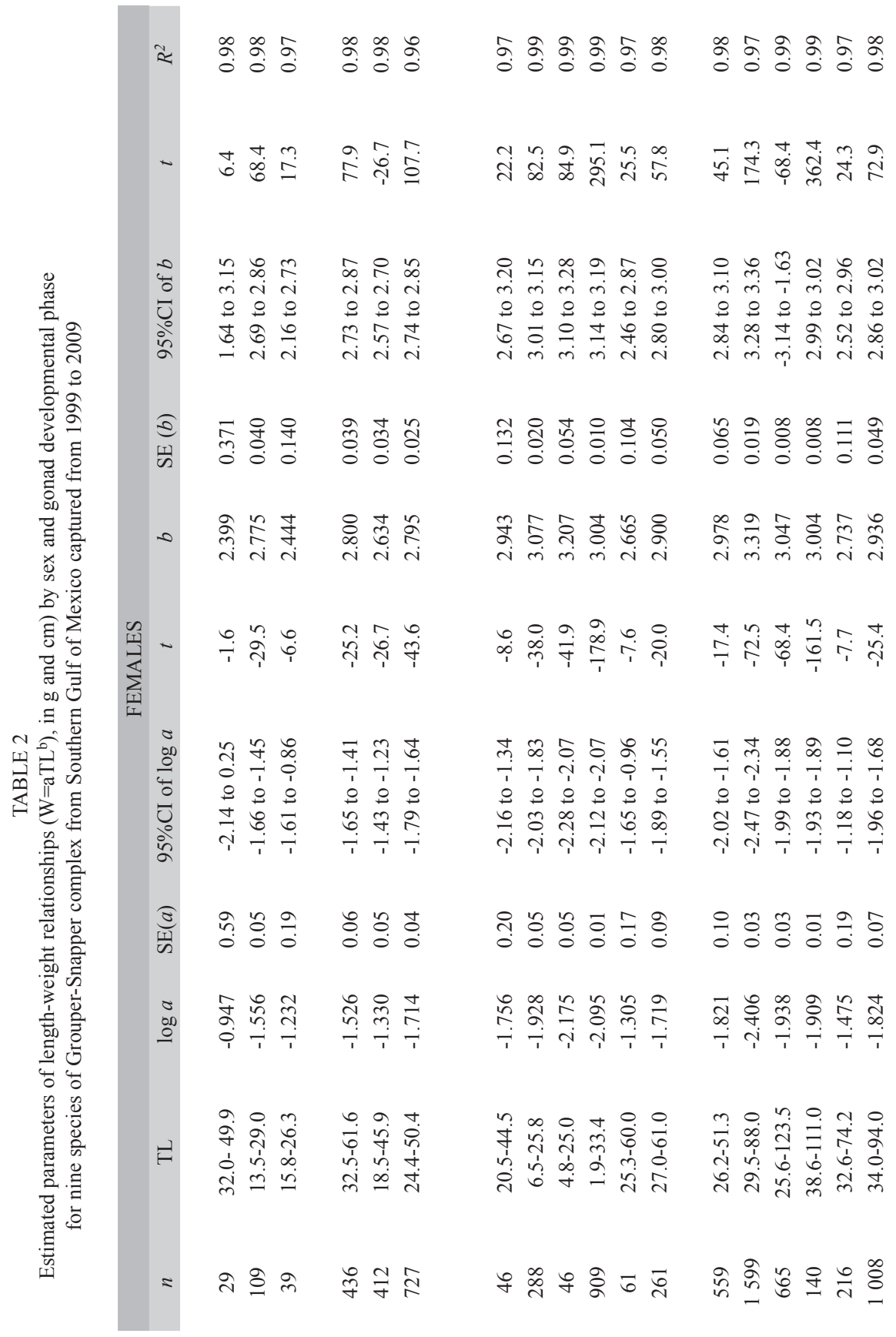

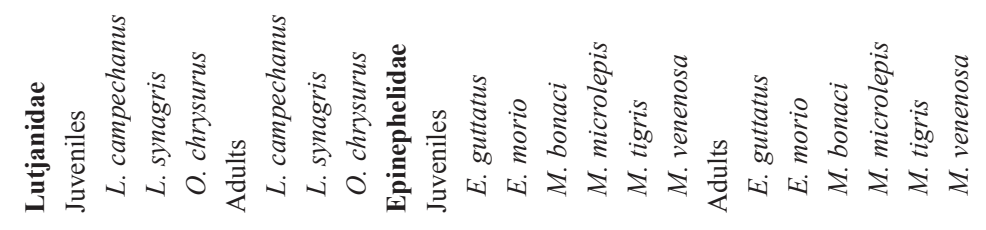




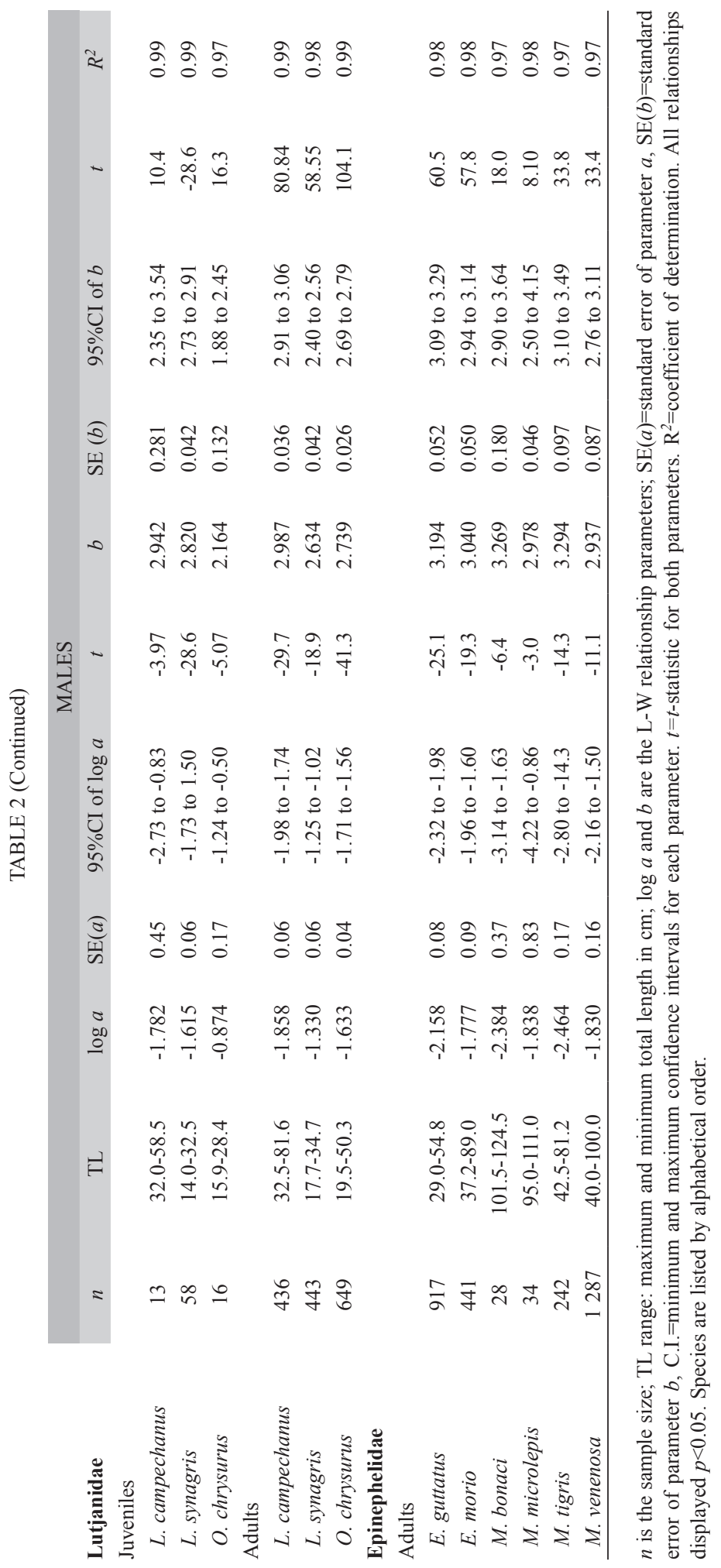

Cc) 
TABLE 3

Results of $t$-test for $b$-value (slope) to acknowledge differences from the allometric coefficient $b=3$ in nine species of the Grouper Snapper complex from Southern Gulf of Mexico captured from 1999 to 2009

Lutjanidae

Juveniles

L. campechanus
L. synagris
O. chrysurus
Adults
L. campechanus
L. synagris
O. chrysurus

Epinephelidae

Juveniles

E. guttatus

E. morio

M. bonaci

M. microlepis

M. tigris

$M$. venenosa

Adults

E. guttatus

E. morio

M. bonaci

M. microlepis

M. tigris

$M$. venenosa

\section{Lutjanidae}

Juveniles
L. campechanus
L. synagris
O. chrysurus

Adults

L. campechanus

L. synagris

O. chrysurus

Epinephelidae

Adults

\begin{tabular}{lcccccc} 
E. guttatus & 3.194 & 0.052 & 0.1174 & 915 & 1.419 & 0.0044 \\
E. morio & 3.040 & 0.050 & 0.1129 & 439 & $9.067^{* *}$ & $<0.0001$ \\
M. bonaci & 3.269 & 0.180 & 0.0496 & 26 & 1.497 & 0.0011 \\
M. microlepis & 2.978 & 0.046 & 0.0621 & 32 & 1.965 & 0.0039 \\
M. tigris & 3.294 & 0.097 & 0.1319 & 240 & 1.905 & 0.0001 \\
M. venenosa & 2.937 & 0.087 & 0.1550 & 1285 & $4.445^{*}$ & $<0.0001$ \\
\hline
\end{tabular}

$b$-value from the $\mathrm{L}-\mathrm{W}$ relationship $\left(\mathrm{W}=\mathrm{aTL}^{\mathrm{b}}\right), \mathrm{SE}(b)=$ standard error of $b$, SE Model=standard error of the $\mathrm{L}-\mathrm{W}$ relationship, d.f. $=$ degrees of freedom, $t=t$-Student statistic and $p=$ probability value. Asterisks denote significant statistical differences of $b$-value from $b=3$ considering $* t$ when $b<3$ and $* * t$ when $b>3$. Species are listed by alphabetical order.

0.0814
0.1555
0.0465
0.0551
0.0756
0.0827

27
107
37

$5.327 *$

$<0.0001$

2.775

0.040

0.140

434

410

$3.872 *$

$<0.0001$

2.634

0.039
0.034

725

1.432
1.767

0.0033

2.943
3.077
3.207
3.004
2.665
2.900

0.132

0.1473

0.0887

0.0851

0.054

0.1162

0.1341

0.104

0.0973

\section{4}

0.157

0.3897

286

$2.913 * *$

$<0.0001$

44

$6.019 * *$

$<0.0001$

907

$21.363 * *$

$<0.0001$

259

$3.840^{*}$

$<0.000$

1.195

0.0044

$\begin{array}{cccccc}2.978 & 0.065 & 0.1724 & 557 & 2.266^{* *} & <0.0001 \\ 3.319 & 0.019 & 0.1270 & 1597 & 18.89^{* *} & <0.0001 \\ 3.047 & 0.008 & 0.0747 & 663 & 3.161^{* *} & <0.0001 \\ 3.004 & 0.008 & 0.0728 & 138 & 0.247^{* *} & 0.0003 \\ 2.737 & 0.111 & 0.1341 & 214 & 0.123 & 0.0150 \\ 2.936 & 0.049 & 0.1525 & 1006 & 3.711^{*} & <0.0001 \\ b & \text { SE }(b) & \text { SE Model } & \text { d.f. } & t & p\end{array}$

$\begin{array}{lccccc}2.942 & 0.281 & 0.0486 & 11 & 1.697 & 0.0021 \\ 2.820 & 0.042 & 0.0535 & 56 & 3.473^{*} & <0.0001 \\ 2.164 & 0.132 & 0.0714 & 14 & 6.318^{*} & <0.0001 \\ & & & & & \\ 2.987 & 0.036 & 0.0519 & 433 & 6.486^{*} & <0.0001 \\ 2.634 & 0.042 & 0.0540 & 441 & 9.066^{*} & <0.0001 \\ 2.739 & 0.026 & 0.0592 & 647 & 6.574^{*} & <0.0001\end{array}$

\section{FEMALES}

$b \quad \operatorname{SE}(b)$

SE Model 


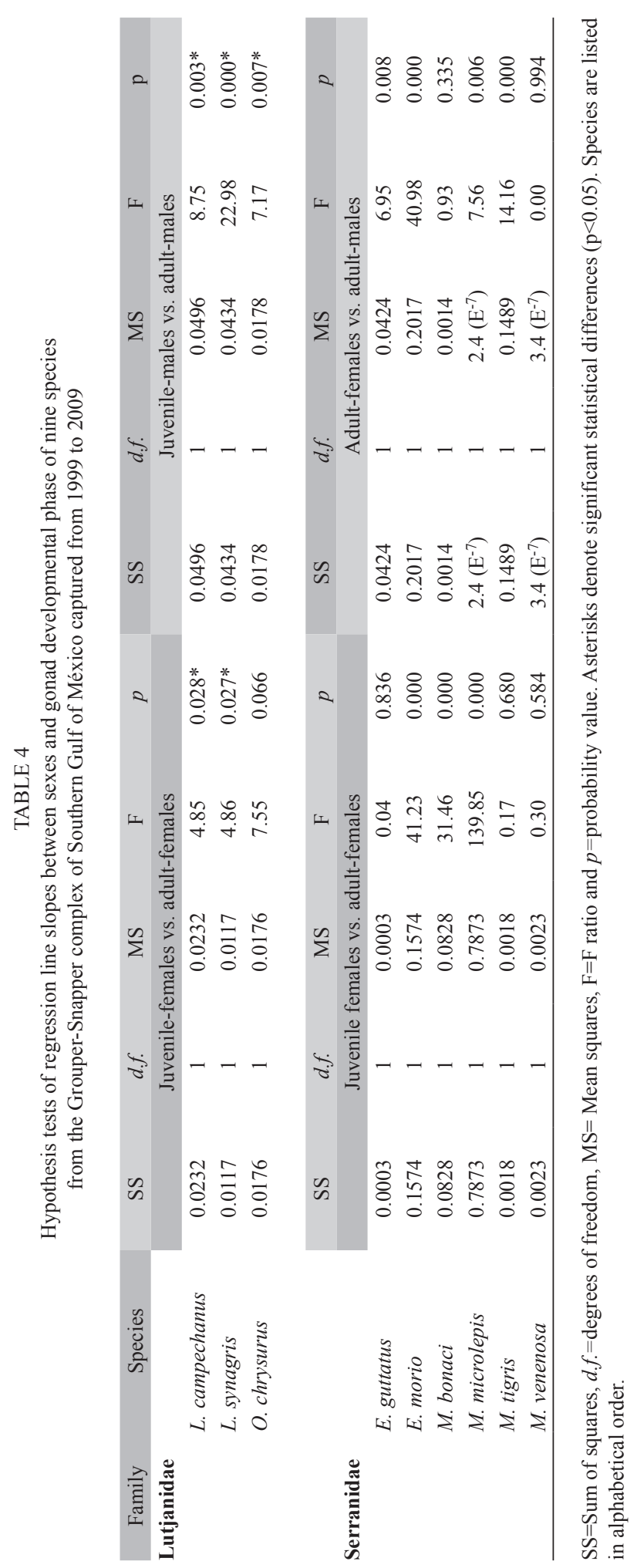


many different levels of detail (Craig, 1984; Enberg, Dunlop, \& Jørgensen, 2008) in order to provide a realistic growth scheme for the species. Froese (2006) suggested a series of recommendations when calculating L-W relationships and noted that L-W relationship for juveniles (many of which do not have the adult body shape) should be calculated separately form adults to avoid the overall regression to be overestimated, since younger individuals (or premature) tend to grow at faster rates. Nevertheless, many of the published data for L-W relationships for different species do not separate juveniles nor females and males.

The evident difference between juveniles and adults for both sexes in gonochoric Snappers showed that growth stanzas could be observed from the juvenile phase to adults (sexually mature) if L-W relationships are obtained separately. Differences between sexes (for adults only) could also be appreciated even though we did not perform a direct comparison between adults: L. synagris, L. campechanus and $O$. chrysurus adult-females were bigger and heavier than adult-males. Trejo-Martínez (2011) and Brulé, Colás- Marrufo, Pérez-Díaz and Sámano-Zapata (2010) reported that in all three Snapper species males reach sexual maturity earlier and at smaller sizes than females. Mean gonadosomatic index was even bigger in males $(3.30 \pm 0.23-0.50 \pm 0.03 \%)$ of Ocyurus chrysurus than in females $(2.30 \pm 0.13$ $0.50 \pm 0.03 \%$ ) suggesting that there is an important deviation of surplus energy canalized to reproduction in males. Reproductive investment reduces the energy necessary for somatic growth, causing a growth rate descend prior to the reproductive season (Lester et al., 2004). Therefore, L-W relationships should be calculated for these species by sex.

For hermaphrodite Groupers, growth stanzas were only observed in E. morio, $M$. bonaci and $M$. microlepis juvenile-females to adultfemales. These results may be due to the size of the juveniles registered for E. morio, $M$. bonaci and $M$. microlepis (from $1.9 \mathrm{~cm}$ to $33.4 \mathrm{~cm}$ ) in comparison to juveniles of $E$. guttatus, M. tigris and M. venenosa $(20.5 \mathrm{~cm}$ to
$61.0 \mathrm{~cm})$. Since Groupers have slow growth rate and late sexual maturity (Coleman et al., 1999) and juveniles where characterized based on their gonadal developmental phase, sexual immature individuals could still be present at large sizes. As a result, growth stanzas could only be identified in smaller juvenile individuals (possibly below $30 \mathrm{~cm}$ TL) that indeed display a different W-L relationship than larger juvenile specimens.

Groupers' growth stanzas from adultfemales to adult-males were observed in $E$. guttatus, E. morio, M. microlepis and M. tigris. Gonadosomatic index for all species was up to three times higher in adult-females than in adult-males, which indicate that there is also, an important amount of energy directed to gonadal development in females. Munday, Hodges, Choat and Gus (2004) registered the existence of a sex-specific growth effect in other species of protogynic hermaphrodites, suggesting that females that become males grow faster than other females before the age of sex change. Only the largest female in a social group becomes male, suppressing sex change in subordinate females (Francis, 1992). Therefore different growth stanzas between sexes in Groupers were expected. Nevertheless, $M$. bonaci and $M$. venenosa did not register differences in L-W relationship slopes between adult females vs. males, even though $M$. bonaci displayed changes in body shape. Since $M$. venenosa maintain the same uniform shape regardless of the sex change, no growth stanzas between adult-females and adult-males could be observed.

Growth stanzas could be registered for gonochoric Snappers mainly due to gonadal development and in hermaphrodite Groupers due to gonadal development and sex change. These results corroborate that a single regression will not adequately describe the lengthweight relationship of a species. It must be considered that growth rate is not constant and may change either continuously or abruptly during the fish lifetime (Katsanevakis et al., 2007) due to genetics, ontogenetic shifts in diet, differences in seasons, sexes, gonad 
development or number of specimens examined (Andreu-Soler, Oliva-Paterna, \& Torralva, 2006). Therefore, the identification of growth stanzas in L-W relationships is imperative not only to obtain a better knowledge of the growth process in reef fishes, but to establish an accurate growth rate used to calculate some target reference points such as maximum sustainable yield or yield-per-recruit used in fisheries management. This study demonstrates the presence of growth stanzas related to gonadal development in Groupers and Snappers and to sex change in Groupers. Therefore, we suggest that the determination of $\mathrm{L}-\mathrm{W}$ relationships, at least for these families, should be done separating juveniles from adults and females from males in order to avoid an overestimation or a mistaken growth rate.

\section{ACKNOWLEDGMENTS}

This study was funded by CONACyT 2184P-B9507 and 37606-B, CONACyT- SEP 49963/2411 and SAGARPA-Yucatan State Government. Authors are grateful for the technical assistance provided by Teresa ColásMarrufo and Jorge Montero-Muñoz.

\section{RESUMEN}

Etapas de crecimiento en un complejo Epinephelidae-Lutjanidae: consideraciones al cálculo de las relaciones peso-longitud. Distintos estados o estanzas de crecimiento descritos por cambios en el ritmo de crecimiento, se pueden observar en peces a lo largo de su vida ya que presentan crecimiento indeterminado. A través del análisis de relaciones longitud-peso (L-P), se identificaron distintas estanzas de crecimiento considerando el tipo de sexualidad, sexo y madurez sexual de individuos de tres especies de pargos (Lutjanidae) gonocóricos y seis de meros (Epinephelidae) hermafroditas protóginos. Pruebas independientes de ANOVA de Welch se aplicaron para conocer si existían diferencias estadísticas significativas en la media de la longitud y peso de juveniles, adultos, hembras y machos de pargos y en juveniles hembras, hembras y machos de meros. De acuerdo a las diferencias observadas, se procedió al cálculo de la relación L-P, parámetros $a$ y $b$, error estándar ( $\mathrm{SE} b$ ) y coeficiente de determinación $\left(R^{2}\right)$ por separado (juveniles, adultos, hembras y machos) para cada especie. Los valores del parámetro $b$ para todas las especies se encontraron dentro del rango esperado de 2.5 a
3.5 para pendientes de la relación L-P en peces. Los pargos tuvieron valores de $b$ : juveniles de hembras de 2.44-2.77, juveniles de machos 2.16-2.94, hembras adultas 2.63-2.80 y machos adultos 2.63-2.98. Los meros tuvieron un valor de $b$ para juveniles de hembras: 2.66-3.20, adultos hembras: 2.73-3.31 y adultos de machos: 2.93-3.29. Para cada relación, el valor de $b$ fue probado a través de una prueba de $t$-Student para explorar diferencias significativas del coeficiente alométrico $(b=3)$, lo cual indicaría cambios en la forma del cuerpo de los individuos. Finalmente pruebas de hipótesis sobre las diferencias entre pendientes obtenidas de las relaciones L-P mostraron distintas estanzas de crecimiento relacionadas en pargos con el desarrollo gonadal y en meros con el desarrollo gonadal pero también con el cambio de sexo. A través de este estudio se pudo observar la existencia de distintas estanzas de crecimiento en especies de alta importancia comercial para el Sur del Golfo de México. Por lo tanto se recomienda la obtención de las relaciones L-P por separado según el sexo y desarrollo gonadal de cada especie, para evitar una sobre estimación o un cálculo erróneo de la tasa de crecimiento poblacional la cual se utiliza en manejo de las pesquerías para determinar algunos puntos de referencia como el criterio de máximo rendimiento sostenible o bien el criterio de rendimiento por recluta.

Palabras clave: estanzas de crecimiento, relaciones longitud-peso, complejo mero-pargo, Golfo de México.

\section{REFERENCES}

Andreu-Soler, A., Oliva-Paterna, F. J., \& Torralva, M. (2006). A review of length-weight relationships of fish from the Segura River basin (SE Iberian Peninsula). Journal of Applied Ichthyology, 22, 295-296.

Brown-Peterson, N., Wyanski, D., Saborido-Rey, F., Macewicz, B., \& Lowerre-Barbieri, S. (2011). A standardized terminology for describing reproductive development in fishes. Marine and Coastal Fisheries: Dynamics, Management, and Ecosystem Science, 3(1), 52-70.

Brulé, T., Nóh-Quiñones, V., Sánchez-Crespo, M., ColásMarrufo, T., \& Pérez-Díaz, E. (2009). Composición de las capturas comerciales del complejo mero-pargo en el sureste del Golfo de México e implicaciones para el manejo de su pesquería. Gulf and Caribbean Fisheries Institute Proceedings, 61, 199-209.

Brulé, T., Colás-Marrufo, T., Pérez-Díaz, E., \& SámanoZapata, J. C. (2010). Red Snapper reproductive biology in the Southern Gulf of Mexico. Transactions of the American Fisheries Society, 139, 957-968.

Burgos, R., \& Defeo, O. (2004). Long-term population structure, mortality and modeling of a tropical multifleet fishery: The Red Grouper Epinephelus morio 
of the Campeche Bank, Gulf of Mexico. Fisheries Research, 66, 325-521.

Burgos, R., \& Pérez-Pérez, M. (2006). Mero Epinephelus morio. In Instituto Nacional de la Pesca (Eds.), Sustentabilidad y pesca responsable en México, evaluación y manejo (pp. 505-521). Retrieved from www. sagarpa.gob.mx

Cinco, E. (1982). Length-weight relationships in fishes. In D. Pauly, \& A. N. Mines (Eds.), Small-scale fisheries of San Miguel Bay, Philippines: biology and stock assessment (pp. 34-37). Quezon City, Philippines: Institute of Fisheries Development and Research, University of the Philippines in the Visayas.

Coleman, F. C., Koenig, C. C., Eklund, A. M., \& Grimes, C. B. (1999). Management and conservation of temperate reef fishes in the Grouper-Snapper complex of the southeastern United States. In J. A. Musick (Ed.), Life in the slow lane: ecology and conservation of long-lived marine animals (pp. 233-242). Bethesda, Maryland: American Fisheries Society, Symposium 23.

Craig, J. F. (1984). Aging in fish. Canadian Journal of Zoology, 63, 1-8.

Dubey, V. K., Sarkar, U. K., Kumar, R. S., Mir, J. I., Pandey, A., \& Singh-Lakra, W. (2012). Length-weight relationships (LWRs) of 12 Indian freshwater fish species form an un-impacted tropical river of Central India (River Ken). Journal of Applied Ichthyology, 28, 854-856.

Enberg, K., Dunlop, E. S., \& Jørgensen, C. (2008). Fish growth. In S. E. Jørgensen, \& B. D. Fath (Eds.), Encyclopedia of Ecology (pp. 1564-1571). Philadelphia PA: Elsevier Inc.

Francis, R. C. (1992). Sexual lability in teleosts: developmental factors. The Quarterly Review of Biology, 67, 1-18.

Froese, R. (2006). Cube law, condition factor and weightlength relationships: history, meta-analysis and recommendations. Journal of Applied Ichthyology, 22, 241-253.

IUCN (International Union for Conservation of Nature and Natural Resources). (2013). IUCN red list of threatened species. Version 2013.2 Retrieved from http:// wwww.iucnredlist.org

Katsanevakis, S., Thessalou-Legaki, M., Karlou-Riga, C., Lefkaditou, E., Dimitriou, E., \& Verriopoulos, G. (2007). Information- theory approach to allometric growth of marine organisms. Marine Biology, 151, 949-959.

Keller, H. R., \& Kerstetter, D. W. (2013). Length-length and length-weight relationships of oilfish (Ruvettus pretiosus), escolar (Lepidocybium flavobrunneum), snake mackerel (Gempylus serpens), and longnose lancetfish (Alepisaurus ferox) form the Gulf of
Mexico and the western North Atlantic Ocean. Journal of Applied Ichthyology, 30, 241-243.

Lester, N. P., Shuter, D. J., \& Abrams, P. A. (2004). Interpreting the von Bertalanffy model of somatic growth in fishes: the cost of reproduction. Proceeding of the Royal Society of London, 271, 1625-1631.

Morris, A. V., Callum, R. M., \& Hawkins, J. P. (2000). The threatened status of Groupers (Epinephelinae). Biodiversity and Conservation, 9, 919-942.

Moutopoulos, D. K., \& Stergiou, K. I. (2002). Lengthweight and length- length relationships of fish species form the Aegean Sea (Greece). Journal of Applied Ichthyology, 18, 200-203.

Munday, P. L., Hodges, A. L., Choat, J. H., \& Gus, N. (2004). Sex-specific growth effects in protogynous hermaphrodites. Canadian Journal of Fisheries and Aquatic Sciences, 61, 323-327.

NOAA (National Oceanic and Atmospheric Administration). (2011). NOAA Seeks comments on a proposed rule to change Gag, Red grouper, and shallow-water grouper management measures in the Gulf of Mexico-Fisheries Service. Retrieved from http://sero.nmfs.noaa.gov/bulletins/pdfs/2011/ FB11-090_PR_Gulf_Reef_Amendment_32

Pauly, D. (1993). Fishbyte section editorial. Naga, ICLARM Quart. 16, 26.

Ricker, W. E. (1973). Linear regressions in fisheries research. Journal of Fisheries Research Board of Canada, 30, 409-434.

Ricker, W. E. (1979). Growth rates and models. In W. S. Hoar, D. J. Randall, \& J. R. Brett (Eds.), Fish Physiology Vol. VIII. Bioenergetics and growth (pp. 678-738). New York: NY Academic Press.

Sadovy, Y., \& Shapiro, D. Y. (1987). Criteria for the diagnosis of hermaphroditism in fishes. Copeia, 1, 136-156.

Sadovy de Mitcheson, Y., \& Liu, M. (2008). Functional hermaphroditism in teleosts. Fish and Fisheries, 9, $1-43$.

SAFMC (South Atlantic Fishery Management Council). (2013). Species Managed by the South Atlantic Fishery Management Council. Retrieve from http:// www.safmc.net/Portals/6/Library/FMP/SnapGroup/ SnapperGrouperSpecies.pdf

SAGARPA (Secretaría de Agricultura, Ganadería, Desarro1lo Rural, Pesca y Alimentación). (2012). Carta nacional pesquera. In A. López-González (Ed.), Diario Oficial de la Federación DCCVII 18 (pp. 108-109). Retrieve from http://www.dof.gob.mx/nota_detalle. php? codigo $=5265388 \&$ fecha $=24 / 08 / 2012$

Shapiro, D. Y. (1987). Reproduction in Groupers. In J. J. Polovina, \& S. Ralston (Eds.), Tropical Snappers and Groupers: Biology and Fisheries Management (pp. 295-327). Boulder, Colorado: Westview Press. 
Sokal, R. R., \& Rohlf, J. (1995). Biometry. The principles and practices of statistics in biological research $\left(3^{\text {rd }}\right.$ ed.). New York: W.H. Freeman and Company.

Trejo-Martínez, J. (2011). Reproductive traits and strategy of two Snappers (Lutjanus synagris and Ocyurus chrysurus) from the continental platform of the Yucatan Peninsula, south-eastern Gulf of Mexico
(Doctoral dissertation). CINVESTAV-I.P.N., Mérida, Yucatán, Mexico.

Welch, B. L. (1951). On the comparison of several mean values: An alternative approach. Biometrika, 38, 330-336.

Zar, J. H. (1999). Biostatistical Analysis. New Jersey: Pearson Prentice Hall. 
